\title{
Faktor Yang Mempengaruhi Kepatuhan Berobat Pasien Yang Diterapi Dengan Tamoxifen Setelah Operasi Kanker Payudara
}

\author{
Arif Budiman*, Daan Khambri*, Hafni Bachtiar**
}

\begin{abstract}
Abstrak
Banyak faktor yang mempengaruhi kepatuhan berobat pasien yang diterapi dengan tamoxifen setelah operasi kanker payudara. Pada penelitian ini bertujuan untuk mengetahui faktor apa saja yang dapat mempengaruhi kepatuhan berobat pasien di RS. Dr. M Djamil, Padang. Sehingga dapat menjadi masukan dan perbaikan untuk meningkatkan kepatuhan berobat pasien. Metode yang digunakan adalah wawancara langsung, penderita mengisi daftar pertanyaan (kuesioner) dan skala likert pelayanan tenaga medis. Periode penelitian dilakukan selama 3 bulan. Analisis univariat, bivariat dan multivariat dilakukan dengan memakai SPSS versi 18.00. Dari 61 pasien didapatkan 9 pasien tidak patuh terapi tamoxifen, hasil penelitian bivariat didapatkan hubungan yang bermakna antara kepatuhan dengan umur, tingkat pendidikan, pendapatan keluarga, ketersediaan asuransi kesehatan dan pelayanan tenaga medis $(p<0,05)$ sedangkan efek samping tidak berhubungan dengan kepatuhan $(p>0,05)$. Analisis multivariat didapatkan faktor yang paling berpengaruh adalah pelayanan tenaga medis dengan $p=0,06$. Dapat disimpulkan bahwa pelayanan medis merupakan faktor yang paling berpengaruh terhadap kepatuhan berobat pasien yang diterapi tamoxifen setelah operasi kanker payudara, faktor lain yang berpengaruh adalah umur, tingkat pendidikan, pendapatan keluarga dan ketersediaan asuransi kesehatan. Hasil penelitian ini dapat menjadi masukan pada tenaga medis sehingga dapat meningkatkan kepatuhan berobat pasien.
\end{abstract}

Kata kunci: Kepatuhan, tamoxifen, kanker payudara.

\begin{abstract}
Many factors affect compliance of treatment in patients treated with tamoxifenAfter breast cancer surgery. This study aims to determine the factors that may affect treatment compliance of patients in the hospital. Dr.M.Djamil, Padang. So it can be sugestion and improvement to enhance patients treatment compliance.Methods. The method is a direct interview, patients filled out a questionnaire (questionnaire) and Likert scale medical services. Period of research carried out for 3 months. Analysis univariat, bivariat and multivariat performed by using SPSS version 18.00. Results. Of the 61 patients we found 9 patients not adherent tamoxifen therapy, the results bivariant a significant association between adherence to the age, level of education, familylncome, availability of health insurance and medical care $(p<0.05)$. Multivariate analysis found that the most influential factor is the care of medical personnel with $p=0.06$. Discussion. It can be concluded that the medical services are the most influential factor on treatment compliance of patients receiving tamoxifen after breast cancer surgery, other factors are age, education level, family income and the availability of health insurance. The results of this study can be suggestion on the medical staff so as to improve treatment compliance of patients.
\end{abstract}

Keywords:Compliance, tamoxifen, breast cancer.

Affiliasi penulis

*Bagian Bedah, Fakultas Kedokteran Universitas Andalas, Padang

**Bagian IImu Kesehatan Masyarakat, Fakultas Kedokteran Universitas Andalas, Padang

Korespondensi :arifsurgeon75@yahoo.com

\section{PENDAHULUAN}

Kanker payudara merupakan jenis kanker yang sering ditemui pada wanita di dunia, meliputi $16 \%$ dari semua jenis kanker yang diderita oleh wanita. Sebanyak 519.000 wanita dilaporkan mengalami kematian akibatnya pada tahun $2004 .^{(1)}$

Dari 600.000 kasus kanker payudara baru yang didiagnosis setiap tahunnya sebanyak 350.000 diantaranya ditemukan di negara maju, sedangkan sisanya ditemukan di negara yang sedang berkembang. Di Amerika Serikat, kira-kira 175.000 wanita didiagnosis menderita kanker payudara (yang dikutip oleh Pane M pada tahun 2002). ${ }^{(2)}$ Di sebagian besar negara di Asia, insiden kanker payudara berdasarkan Age Standardized Ratio (ASR) masih rendah walaupun angka tersebut mencapai lebih dari 50 per 100.000 penduduk (world standardized rate) di Manila, Filipina dan Karachi selatan, Pakistan. ${ }^{(3)}$
Kanker payudara merupakan penyebab utama dalam hal insiden dan kematian yang terjadi akibat kanker pada wanita. Pada tahun 2000 insiden kanker payudara di Indonesia berdasarkan ASR adalah sebesar 20,6 (20,6 per 100.000 penduduk) dengan mortalitas sebesar 10,1 (10,1 per 100.000 penduduk) atau se banyak 10.753 orang. Sedangkan pada tahun 2005 mortalitas akibat kanker payudara menurut ASR adalah sebesar 10,9 per 100.000 penduduk dengan jumlah kematian sebanyak 12.352 orang. Kanker payudara merupakan masalah kesehatan masyarakat yang penting, karena morbiditas dan mortalitasnya yang tinggi. ${ }^{(4)}$

Kanker payudara merupakan kanker kedua terbanyak setelah kanker leher rahim pada wanita di Indonesia. ${ }^{(5)}$ Selain itu menurut data GLOBOCAN, IARC (2002), insiden kanker payudara di Indonesia berdasarkan ASR adalah sebesar 26 per 100.000 penduduk wanita dengan mortalitas mencapai 11,3 per 100.000 penduduk wanita. ${ }^{(6)}$

Penatalaksanaan kanker payudara dilakukan dengan serangkaian pengobatan meliputi pembedahan, kemoterapi, radiasi, hormonal dan terapi imunologik. Pengobatan ini ditujukan untuk 
memusnahkan kanker atau membatasi perkembangan penyakit serta menghilangkan gejalanya. Kanker payudara memiliki hubungan yang erat dengan hormon estrogen pada wanita. Hormon inilah yang dianggap sebagai salah satu faktor penyebab terjadinya kanker payudara. Terapi hormonal dapat menghambat pertumbuhan tumor yang peka terhadap hormon tersebut dan dapat dipakai sebagai terapi pendamping setelah pembedahan atau pada kanker stadium akhir. ${ }^{(7)}$

Terapi hormonal diindikasikan hanya pada payudara yang menunjukkan ekspresi positif terhadap reseptor estrogen (ER) dan atau reseptor progesteron (PR). Salah satu terapi hormonal yang banyak digunakan adalah blockade reseptor dengan menggunakan selective estrogen receptor modulator (SERM), misalnya tamoxifen. ${ }^{(8)}$

Kurang lebih $75 \%$ wanita yang menderita kanker payudara telah mendapatkan terapi hormonal dengan tamoxifen. Hal ini terutama bertujuan untuk mengurangi risiko timbulnya kanker kembali di masa yang akan datang. Sekitar satu dari tiga wanita penderita kanker payudara yang pernah menjalani terapi tamoxifen, berhenti menggunakan terapi tersebut sebelum masa akhir yang direkomendasikan yaitu 5 tahun terapi. Pasien kanker payudara reseptor estrogen positif yang diterapi tamoxifen selama lima tahun akan berkurang angka kekambuhan sebesar $46 \%$ dan angka kematian akan menurun sebesar $26 \%{ }^{(9)}$

Berdasarkan penelitian yang dilakukan oleh D r. Barron dari Trinity College Dublin yang dimuat dalam jurnal Cancer edisi 1 Maret 2007 menyatakan bahwa $22 \%$ wanita berhenti menggunakan obat tersebut dalam kurun waktu 1 tahun dan $28 \%$ dalam 2 tahun. Setelah 3,5 tahun, sekitar 35\% telah berhenti menggunakan tamoxifen tanpa beralih kepada terapi lain sebagai pengganti. Wanita yang berusia lebih muda (35 sampai 45 tahun) dan wanita yang berusia lebih tua (di atas 75 tahun) I ebih banyak berhenti menggunakan tamoxifen. Demikian pula halnya dengan wanita yang pernah diberikan resep antidepresan di masa lalu, yang merupakan suatu indikasi bahwa mereka pernah mengalami depresi. ${ }^{(10)}$

Penelitian yang dilakukan Timothy L.Lash dari Department of Epidemiology Boston University yang dimuat dalam jurnal Breast Cancer Research and Treatment 2006 didapatkan 20\% wanita dengan pendidikan rendah dan $22 \%$ dengan pendidikan tinggi berhenti menggunakan tamoxifen, $18 \%$ wanita dengan ekonomi rendah dan $22 \%$ dengan ekonomi baik berhenti menggunakan tamoxifen dan $26 \%$ wanita menghentikan terapi karena efek samping terapi. ${ }^{(11)}$ Kepatuhan menurut Gatchel RJ, Baum A dan Krantz DS pada tahun 1989 (yang dikutip oleh Widyanti K pada tahun 2008) adalah melakukan seperti apa yang disarankan oleh dokter atau mengikuti saran untuk mengadopsi tingkah laku tertentu yang berkaitan dengan kesehatan. Meminum obat saat disarankan untuk minum dan tidak menghentikan sebelum disarankan. Ketidakpatuhan dapat mendatangkan beberapa konsekuensi yang harus ditanggung oleh pasien. Beberapa mungkin tidak menyakitkan tapi beberapa yang lain dapat mendatangkan masalah yang serius. Ada beberapa faktor yang dapat memprediksi tingkat kepatuhan individu pada saran medis yaitu : karakteristik penyakit yang diderita, karakteristik personal, norma budaya dan interaksi antara dokter dan $\mathrm{p}$ asien. ${ }^{(12)}$
Karena belum adanya data mengenai persentase, angka kepatuhan dan faktor-faktor yang mempengaruhi kepatuhan berobat pasien yang diterapi dengan tamoxifen setelah operasi kanker payudara maka peneliti ingin melakukan penelitian ini.

\section{METODE PENELITIAN}

Penelitian ini dilakukan dengan mengambil data di Medical Record, Poli Bedah RS. Dr. M Djamil Padang dan kunjungan ke rumah. Banyak faktor yang mempengaruhi kepatuhan berobat pasien yang diterapi dengan tamoxifen setelah operasi kanker payudara. Di Padang sendiri belum ada data mengenai kepatuhan berobat pasien yang diterapi dengan tamoxifen setelah operasi Kanker payudara dan faktor apa yang mempengaruhi kepatuhan berobat.

Populasi atau subjek penelitian ini telah memenuhi kriteria inklusi yaitu kelompok pasien wanita yang mendapat terapi tamoxifen setelah operasi kanker dan setuju diikutsertakan dalam penelitian. Sample yang di gunakan berjumlah 61 sample.

Penelitian mengenai kepatuhan berobat pasien yang diterapi dengan tamoxifen setelah operasi Kanker payudara dan faktor apa yang mempengaruhi kepatuhan berobat tersebut. Pengumpulan data dilakukan dengan menggunakan kuesioner yang meliputi kepatuhan berobat pasien dan variablevariabel yang mempengaruhi kepatuhan berobat pasien yang diterapi dengan tamoxifen setelah operasi kanker payudara, seperti Umur, Tingkat pendidikan, Pendapatan Keluarga, Ketersediaan asuransi kesehatan, Efek samping tamoxifen dan Pelayanan tenaga medis.

Proses pengumpulan datanya langsung di tujukan pada pasien yang datang ke poliklinik Bagian Bedah, Sub Divisi Bedah Onkologi yang mendapat terapi tamoxifen setelah operasi kanker payudara, kunjungan kerumah dan dari Berkas Rekam Medis. Pada pasien yang memenuhi kriteria inklusi diberikan berkas kuesioner dan diisi langsung oleh pasien dan pada pasien yang memenuhi kriteria inklusi tapi tidak datang ke poli dilakukan kunjungan ke rumah berdasarkan data yang didapat dari medical record. Periode penelitian ini dilakukan dari 1 Februari 2012 sampai 30 Mei 2012. Jenis penelitian ini yang digunakan penelitian observasional dengan rancangan cross-sectional dimana variable independen dan varibel dependen diteliti dalam waktu yang sama.

\section{HASIL}

Telah dilakukan penelitian dengan menggunakan desain cross sectional terhadap 61 responden penelitian yang memenuhi kriteria insklusi dan eksklusi pada pasien yang mendapat tamoxifen setelah operasi kanker payudara, 


\section{Analisis Univariat}

Distribusi Frekuensi Responden Berdasarkan Umur

Tabel 1. Distribusi frekuensi responden berdasarkan umur

\begin{tabular}{cccc}
\hline & & Umur & \\
\hline Kepatuhan & $\mathrm{F}$ & $\begin{array}{c}\text { Rata- } \\
\text { rata }\end{array}$ & $\begin{array}{c}\text { Standar } \\
\text { Deviasi }\end{array}$ \\
\hline Patuh & 52 & 52,57 & 7,62 \\
Tidak & 9 & 46,00 & 10,39 \\
Patuh & & & \\
\hline
\end{tabular}

Dari hasil penelitian didapatkan 52 responden penelitian patuh dengan umur rata-rata 52.57 dan 9 responden penelitian tidak patuh dengan umur ratarata 46.00 .

\section{Distribusi Frekuensi Responden Berdasarkan Tingkat Pendidikan}

Tabel 2. Distribusi frekuensi responden berdasarkan tingkat pendidikan

\begin{tabular}{|c|c|c|}
\hline Pendidikan & $\mathrm{F}$ & $\%$ \\
\hline Rendah & 10 & 16,4 \\
\hline Tinggi & 51 & 83,6 \\
\hline Total & 61 & 100 \\
\hline \multicolumn{3}{|c|}{$\begin{array}{l}\text { Hasil penelitian menunjukkan seb } \\
\text { berpendidikan tinggi } 51 \text { responden }(83,6\end{array}$} \\
\hline \multicolumn{3}{|c|}{$\begin{array}{l}\text { Distribusi Frekuensi Responden Berd } \\
\text { Pendapatan Keluarga } \\
\text { Tabel 3. Distribusi frekuensi responden } \\
\text { pendapatan keluarga }\end{array}$} \\
\hline Pendapatan & $\mathrm{F}$ & $\%$ \\
\hline Rendah & 6 & 9,8 \\
\hline Tinggi & 55 & 90,2 \\
\hline Total & 61 & 100 \\
\hline
\end{tabular}

Hasil penelitian menunju kkan umumnya responden berpendapatan tinggi 55 responden $(90,2 \%)$.

\section{Distribusi Frekuensi Responden Berdasarkan}

Ketersediaan Asuransi Kesehatan

Tabel 4. Distribusi frekuensi responden berdasarkan ketersediaan asuransi kesehatan

\begin{tabular}{ccc}
\hline $\begin{array}{c}\text { Asuransi } \\
\text { Kesehatan }\end{array}$ & $\mathrm{F}$ & $\%$ \\
\hline Ada & 54 & 88,5 \\
Tidak ada & 7 & 11,5 \\
\hline Total & 61 & 100 \\
\hline
\end{tabular}

Hasil penelitian menunjukkan sebagian besar memiliki asuransi kesehatan 54 responden $(88,5 \%)$.

Distribusi Frekuensi Responden Berdasarkan Efek Samping

Tabel 5. Distribusi frekuensi responden berdasarkan efek samping

\begin{tabular}{ccc}
\hline $\begin{array}{c}\text { Efek } \\
\text { samping }\end{array}$ & $\mathrm{f}$ & $\%$ \\
\hline Ada & 10 & 16,4 \\
Tidak ada & 51 & 83,6 \\
\hline Total & 61 & 100 \\
\hline
\end{tabular}

Hasil penelitian didapatkan 51 responden (83,6 \%) tidak ada efek samping terapi.

\section{Distribusi Frekuensi Responden Berdasarkan Pelayanan Tenaga Medis}

Tabel 6. Distribusi frekuensi responden berdasarkan pelayanan tenaga medis

\begin{tabular}{ccc}
\hline Pelayanan medis & $f$ & $\%$ \\
\hline Baik & 47 & 75,8 \\
Buruk & 14 & 22,6 \\
\hline Total & 61 & 100 \\
\hline
\end{tabular}

Hasil penelitian menunjukkan sebagian besar dengan pelayanan medis baik 47 responden $(75,8 \%)$.

\section{Analisis Bivariat}

Hasil analisis bivariat membahas ada tidaknya hubungan antara umur, tingkat pendidikan, pendapatan, ketersediaan asuransi kesehatan, efek samping dan pelayanan medis dengan kepatuhan berobat pasien yang diterapi dengan tamoxifen setelah operasi kanker payudara.

\section{Hubungan Umur Dengan Kepatuhan Terapi Tamoxifen}

Tabel 7. Hubungan umur dengan kepatuhan berobat pasien yang diterapi tamoxifen setelah operasi kanker payudara.

\begin{tabular}{cccc}
\hline & \multicolumn{2}{c}{ Umur } \\
\hline Kepatuhan & $\mathrm{N}$ & Rata-rata & $\mathrm{p}$ \\
\hline Patuh & 52 & $52.57 \pm 7.62$ & 0,027 \\
Tidak & 9 & $46.00 \pm 10.39$ & \\
Patuh & & & \\
\hline
\end{tabular}

Rata-rata umur responden lebih tinggi pada yang patuh dibandingkan dengan yang tidak patuh (52.57 \pm 7.62). Secara statistik perbedaan ini signifikan $(p<$ $0,05)$.

\section{Hubungan Tingkat Pendidikan Dengan Kepatuhan Terapi Tamoxifen.}

Tabel 8. Hubungan tingkat pendidikan dengan kepatuhan berobat pasien yang diterapi tamoxifen setelah operasi kanker payudara.

\begin{tabular}{|c|c|c|c|c|c|c|c|}
\hline \multirow{3}{*}{$\begin{array}{l}\text { Pendidik } \\
\text { an }\end{array}$} & \multicolumn{4}{|c|}{ Kepatuhan } & \multirow{2}{*}{\multicolumn{2}{|c|}{ Total }} & \multirow{3}{*}{$p$} \\
\hline & \multicolumn{2}{|c|}{ Patuh } & \multicolumn{2}{|c|}{$\begin{array}{l}\text { Tidak } \\
\text { patuh }\end{array}$} & & & \\
\hline & $f$ & $\%$ & $f$ & $\%$ & $f$ & $\%$ & \\
\hline \multirow[t]{2}{*}{ Rendah } & 5 & 50 & 5 & 50 & 1 & 10 & \\
\hline & & & & & 0 & 0 & 0,00 \\
\hline \multirow[t]{2}{*}{ Tinggi } & 47 & 92. & 4 & 7.8 & 5 & 10 & 4 \\
\hline & & 2 & & & 1 & 0 & \\
\hline \multirow[t]{2}{*}{ Jumlah } & 52 & 85. & 9 & 18. & 6 & 10 & \\
\hline & & 2 & & 8 & 1 & 0 & \\
\hline
\end{tabular}

Persentase responden yang patuh lebih tinggi pada pendidikan tinggi dibandingkan pendidikan rendah (47 responden $(92,2 \%))$. Secara statistik perbedaan ini signifikan $(p<0,05)$. 


\section{Hubungan Pendapatan Keluarga Dengan}

Kepatuhan Terapi Tamoxifen.

Tabel 9. Hubungan pendapatan keluarga dengan kepatuhan berobat pasien yang diterapi tamoxifen setelah operasi kanker payudara.

\begin{tabular}{|c|c|c|c|c|c|c|c|}
\hline \multirow{3}{*}{$\begin{array}{c}\text { Pendapata } \\
\mathrm{n}\end{array}$} & \multicolumn{4}{|c|}{ Kepatuhan } & \multirow{2}{*}{\multicolumn{2}{|c|}{ Total }} & \multirow{3}{*}{$P$} \\
\hline & \multicolumn{2}{|c|}{ Patuh } & \multicolumn{2}{|c|}{$\begin{array}{l}\text { Tidak } \\
\text { patuh }\end{array}$} & & & \\
\hline & $f$ & $\%$ & $f$ & $\%$ & $f$ & $\%$ & \\
\hline Rendah & 2 & $\begin{array}{c}33 . \\
3\end{array}$ & 4 & $\begin{array}{c}66 . \\
7\end{array}$ & 6 & $\begin{array}{c}10 \\
0\end{array}$ & 0,00 \\
\hline Tinggi & $\begin{array}{l}5 \\
0\end{array}$ & $\begin{array}{c}90 . \\
9\end{array}$ & 5 & 9.1 & $\begin{array}{l}5 \\
5\end{array}$ & $\begin{array}{c}10 \\
0 \\
\end{array}$ & 3 \\
\hline Jumlah & $\begin{array}{l}5 \\
2\end{array}$ & $\begin{array}{c}85 . \\
2 \\
\end{array}$ & 9 & $\begin{array}{c}14 . \\
8\end{array}$ & $\begin{array}{l}6 \\
1 \\
\end{array}$ & $\begin{array}{c}10 \\
0\end{array}$ & \\
\hline
\end{tabular}

Persentase responden yang patuh lebih tinggi pada yang pendapatan tinggi dibandingkan dengan yang pendapatan rendah ( 50 responden $(90,9 \%)$ ). Secara statistik perbedaan ini signifikan $(p<0,05)$.

\section{Hubungan Ketersediaan Asuransi Kesehatan Dan Kepatuhan Terapi Tamoxifen}

Tabel 10. Hubungan ketersediaan asuransi kesehatan dengan kepatuhan berobat pasien yang diterapi tamoxifen setelah operasi kanker payudara

\begin{tabular}{|c|c|c|c|c|c|c|c|}
\hline \multirow{3}{*}{ Asuransi } & \multicolumn{4}{|c|}{ Kepatuhan } & \multirow{2}{*}{\multicolumn{2}{|c|}{ Total }} & \multirow{3}{*}{$P$} \\
\hline & \multicolumn{2}{|c|}{ Patuh } & \multicolumn{2}{|c|}{$\begin{array}{l}\text { Tidak } \\
\text { patuh }\end{array}$} & & & \\
\hline & $f$ & $\%$ & $f$ & $\%$ & $f$ & $\%$ & \\
\hline Ada & 48 & 88,9 & 6 & 11,1 & 54 & 100 & \\
\hline $\begin{array}{l}\text { Tidak } \\
\text { ada }\end{array}$ & 4 & 57,1 & 3 & 42,9 & 7 & 100 & 0.026 \\
\hline Jumlah & 52 & 85,2 & 9 & 14,8 & 61 & 100 & \\
\hline
\end{tabular}

Persentase responden yang patuh lebih tinggi pada yang memiliki asuransi kesehatan dibandingkan dengan yang tidak memiliki asuransi kesehatan ( 48 responden $(88,9 \%))$. Secara statistik perbedaan ini signifikan $(p<0,05)$.

\section{Hubungan Efek Samping dengan Kepatuhan Terapi Tamoxifen.}

Tabel 11. Hubungan efek samping tamoxifen dengan kepatuhan berobat pasien yang diterapi tamoxifen setelah operasi kanker payudara.

\begin{tabular}{|c|c|c|c|c|c|c|c|}
\hline \multirow{3}{*}{$\begin{array}{c}\text { Efek } \\
\text { samping }\end{array}$} & \multicolumn{4}{|c|}{ Kepatuhan } & \multirow{2}{*}{\multicolumn{2}{|c|}{ Total }} & \multirow{3}{*}{$P$} \\
\hline & \multicolumn{2}{|c|}{ Patuh } & \multicolumn{2}{|c|}{$\begin{array}{l}\text { Tidak } \\
\text { patuh }\end{array}$} & & & \\
\hline & $\mathrm{F}$ & $\%$ & $f$ & $\%$ & $f$ & $\%$ & \\
\hline Ada & 8 & 80 & 2 & 20 & 10 & 100 & \\
\hline $\begin{array}{l}\text { Tidak } \\
\text { ada }\end{array}$ & 44 & 86,3 & 7 & 13,7 & 51 & 100 & 0.633 \\
\hline Jumlah & 52 & 85,2 & 9 & 14,8 & 61 & 100 & \\
\hline
\end{tabular}

Persentase responden yang patuh lebih tinggi pada yang tidak ada efek samping dibandingkan dengan yang ada efek samping ( 44 responden $(86,3 \%)$ ). Secara statistik perbedaan ini tidak signifikan $(p>$ $0,05)$.

\section{Hubungan Pelayanan Tenaga Medis Dengan Kepatuhan Terapi Tamoxifen}

Tabel 12. Hubungan pelayanan tenaga medis dengan kepatuhan berobat pasien yang diterapi tamoxifen setelah operasi kanker payudara.

\begin{tabular}{lccccccc}
\hline \multirow{2}{*}{$\begin{array}{c}\text { Pelayanan } \\
\text { medis }\end{array}$} & \multicolumn{4}{c}{ Kepatuhan } & \multirow{2}{*}{ Total } & \multirow{2}{*}{$\mathrm{P}$} \\
\cline { 2 - 6 } & \multicolumn{4}{c}{ Patuh } & \multicolumn{4}{c}{$\begin{array}{c}\text { Tidak } \\
\text { patuh }\end{array}$} & & & \\
\cline { 2 - 7 } & $\mathrm{f}$ & $\%$ & $\mathrm{f}$ & $\%$ & $\mathrm{f}$ & $\%$ & \\
\hline Baik & 44 & 93,6 & 3 & 6,4 & 47 & 100 & \multirow{2}{*}{0.003} \\
Buruk & 8 & 57,1 & 6 & 42,9 & 14 & 100 & \\
\hline Jumlah & 52 & 85,2 & 9 & 14,8 & 61 & 100 & \\
\hline
\end{tabular}

Persentase responden yang patuh lebih tinggi pada pelayanan medis baik dibandingkan dengan pelayanan medis buruk (44 responden (93,6 \%)). Secara statistik perbedaan ini signifikan $(p<0,05)$.

\section{Analisis Multivariat}

Tabel.13. Analisis multivariat regresi logistic untuk faktor yang mempengaruhi kepatuhan berobat pasien yang diterapi tamoxifen

\begin{tabular}{|ll|c|c|c|}
\hline \multirow{2}{*}{$\begin{array}{l}\text { Faktor } \\
\text { mempengaruhi }\end{array}$} & \multicolumn{2}{|c|}{$95 \%$} & \multirow{2}{*}{$\mathrm{p}$} \\
\cline { 3 - 4 } & lower & Upper & \\
\hline - & Pelayanan & 2,910 & 690.00 & 0,06 \\
medis & & 0,001 & 0,454 & 0,15 \\
- & Pendidikan & 0,635 & 0,954 & 0,16 \\
\hline
\end{tabular}

Faktor yang paling berpengaruh terhadap kepatuhan berobat pasien yang diterapi dengan tamoxifen setelah operasi kanker payudara adalah pelayanan medis dengan $p=0,06$.

\section{PEMBAHASAN}

Penelitian ini menggunakan desain cross sectional yang dilakukan pada 61 responden yang mendapat terapi tamoxifen setelah operasi kanker payudara dengan melakukan uji T-test dan uji ChiSquare test untuk melihat faktor yang mempengaruhi kepatuhan terapi tamoxifen setelah operasi kanker payudara.

Didapatkan 52 responden yang patuh terapi dengan umur rata-rata 52,57 dan 9 responden yang tidak patuh terapi dengan umur rata- rata 46,00 tahun, sebagian besar berpendidikan tinggi 51 responden $(83,6 \%)$, umumnya responden berpendapatan tinggi 55 responden $(90,2 \%)$, sebagian besar memiliki asuransi kesehatan 54 responden $(88,5 \%)$, hanya 10 responden $(16,4 \%)$ dengan efek samping dan sebagian besar dengan pelayanan medis baik 47 responden ( $75,8 \%)$.

Hasil analisis bivariat didapatkan hubungan umur dengan kepatuhan terapi pasien, karena umur mempengaruhi motivasi untuk hidup sehat, semakin bertambah umur semakin tinggi tingkat kepatuhan terapi. Pada penelitian ini didapatkan hubungan yang signifikan antara umur dengan kepatuhan $(p<0,05)$, dimana rata-rata umur responden yang patuh lebih tinggi pada yang patuh dibandingkan dengan yang tidak patuh. Hasil penelitian ini sesuai dengan yang dikemukakan dari penelitian Dr. Barron dari Trinity College Dublin dimana wanita yang berusia terlalu muda dan terlalu tua lebih banyak berhenti terapi tamoxifen. ${ }^{(10)}$ 
Tingkat pendidikan berpengaruh terhadap kepatuhan seseorang, semakin rendah tingkat pendidikan maka semakin tidak patuh penderita untuk berobat karena rendahnya pendidikan seseorang sangat mempengaruhi daya serap seseorang dalam menerima informasi. Pada penelitian ini didapatkan hubungan yang bermakna antara tingkat pendidikan dengan kepatuhan berobat pasien $(p<0,05)$. Hasil penelitian ini sesuai dengan yang dikemukakan oleh beberapa peneliti lain bahwa semakin tinggi pendidikan seseorang maka makin besar kemampuan menyerap, menerima atau mengadopsi informasi. Hasil penelitian ini tidak sesuai dengan penelitian yang dilakukan Timothy L.Lash dari Department of Epidemiology Boston University dimana didapatkan pasien dengan pendidikan tinggi yang banyak berhenti menggunakan tamoxifen. ${ }^{(11)} \mathrm{Hal}$ ini dapat disebabkan oleh bermacam faktor seperti perbedaan jumlah sampel dan rumah sakit tempat pengobatan.

Faktor sosial ekonomi berperan dalam kepatuhan berobat pasien, semakin rendah sosial ekonomi seseorang semakin tidak patuh untuk berobat. Pada penelitian ini didapatkan hubungan yang bermakna antara pendapatan keluarga dengan kepatuhan berobat pasien $(p<0,05)$. Hasil penelitian ini tidak sesuai dengan penelitian yang dilakukan Timothy L.Lash dimana didapatkan pasien dengan pendapatan tinggi yang banyak berhenti menggunakan tamoxifen. ${ }^{(11)} \mathrm{Hal}$ ini disebabkan oleh bermacam faktor seperti perbedaan jumlah sampel, rumah sakit tempat pengobatan dan perbedaan sosial ekonomi negara.

Ketersediaan asuransi kesehatan berperan sebagai faktor kepatuhan berobat pasien, dengan adanya asuransi kesehatan didapatkan kemudahan dari segi pembiayaan sehingga lebih patuh dibandingkan dengan yang tidak memiliki asuransi kesehatan. Didapatkan hubungan yang bermakna antara ketersediaan asuransi kesehatan dengan kepatuhan berobat pasien yang diterapi tamoxifen ( $p$ $<0,05)$.. Hasil penelitian ini tidak sesuai dengan penelitian yang dilakukan Timothy L.Lash dimana didapatkan banyak pasien yang tidak patuh itu yang memiliki asuransi kesehatan. ${ }^{(11)} \mathrm{Hal}$ ini disebabkan oleh rumah sakit tempat pengobatan, perbedaaan jumlah sampel dan perbedaaan sosial ekonomi Negara.

Efek samping dari pengobatan berpengaruh terhadap kepatuhan, semakin tidak menyenangkan efek samping yang timbul semakin tidak patuh pasien berobat. Hasil penelitian didapatkan hubungan yang bermakna antara ada tidaknya efek samping dengan kepatuhan berobat pasien yang diterapi tamoxifen ( $p$ $<0,05)$. Hasil penelitian ini tidak sesuai dengan penelitian yang dilakukan Timothy L.Lash dimana didapatkan pasien yang berhenti terapi tamoxifen karena efek samping obat. ${ }^{(11)} \mathrm{Hal}$ ini disebabkan perbedaan populasi yang diwakili dan perbedaan jumlah sampel.

Kualitas pelayanan medis berpengaruh terhadap kepatuhan. Pelayanan medis yang baik akan membuat pasien patuh dalam berobat. Pada penelitian didapatkan hubungan yang bermakna antara pelayanan tenaga medis dengan kepatuhan berobat pasien yang diterapi dengan tamoxifen $(p<0,05)$. Ada hubungan signifikan antara pelayanan tenaga medis dengan kepatuhan berobat pasien.

Hasil analisis multivariat dari faktor yang mempengaruhi kepatuhan berobat pasien yang diterapi dengan tamoxifen setelah operasi kanker payudara didapatkan faktor pelayanan medis paling berpengaruh terhadap kepatuhan berobat kemudian pendidikan dan umur.

\section{KESIMPULAN DAN SARAN Kesimpulan}

Didapatkan hubungan umur, tingkat pendidikan, pendapatan keluarga, ketersediaan asuransi kesehatan dan pelayanan medis dengan kepatuhan terapi tamoxifen sedangkan efek samping tidak berhubungan dengan kepatuhan terapi tamoxifen. Pelayanan medis merupakan faktor yang paling berpengaruh terhadap kepatuhan berobat pasien.

\section{Saran}

Perlunya pelayanan medis yang baik, informasi yang jelas dari dokter mengenai manfaat dan lama terapi tamoxifen untuk meningkatkan kepatuhan pasien dalam terapi tamoxifen.

\section{DAFTAR PUSTAKA}

1. WHO, World Health Organization. Global Burden of Disease 2004 Update. 2004: 56

2. Pane M. Aspek Klinis dan Epidemiologis Penyakit Kanker Payudara. Tesis Program Pascasarjana IImu Kesehatan Masyarakat Universitas Indonesia, Jakarta, 2002.

3. Bray F, McCarron P, Parkin DM. Review : The changing global patterns of female breast cancer incidence and mortality. Breast Cancer Research 2004;6:229-39.

4. Tjindarbumi. Penanganan Kanker Payudara Masa Kini dengan berbagai Macam Isu di Indonesia. Proceeding Indonesian Issues on Breast Cancer; Surabaya 2004.

5. Tjindarbumi. Diagnosis dan Pencegahan Kanker Payudara, Kursus Singkat Deteksi Dini dan Pencegahan Kanker. 6-8 November. FKC.II-POI. Jakarta. 1995.

6. GLOBOCAN. Database Descriptive Epidemiology Group, IARC 2002. Diakses dari : $\quad$ http://wwwdep.iarc.fr/GLOBOCAN frame.htm.

7. Roche Pharmaceutical. Kanker Payudara. Diakses dari http://www.hompedin.org/download/kankerpa yudara.pdf

8. Suyatno. Kanker Payudara. Bedah Onkologi Diagnostik dan Terapi. Jakarta : Sagung Seto: 2010. hal 35-81.

9. Early Breast Cancer Trialists' Collaborative Group. Tamoxifen for early breast cancer: an overview of the randomised trials. Lancet 1998;351:1451-67.

10. News and Views. Many Women Quit Tamoxifen Prematurely. A Cancer Journal for Clinicians 2007;53:127-8.

11. Lash TL,Fox MP, Westrup JL, Fink AK, Silliman RA. Adherance to tamoxifen over the five-year course. Breast Cancer Research and Treatment 2006;99:215-20.

12. Widyanti K. Hubungan antara jumlah dukungan sosial yang diterima dengan kepatuhan menjalani terapi ARV pada Odha. Tesis FPSI UI, 2008. 